\title{
Waste Bank: Model and Education of Organic and Non Organic Waste Processing in Riau Province
}

\author{
Prama Widayat ${ }^{* 1}$, Budi Hamuddin ${ }^{2}$ and Heppi Syofya ${ }^{3}$
}

\author{
${ }^{1}$ Faculty of Economy, University Lancang Kuning and University of Riau, Indonesia. \\ ${ }^{2}$ Faculty of Teacher Training and Education, University Lancang Kuning of Riau, Indonesia. \\ ${ }^{3}$ Institute of Economic Science Sakti Alam Kerinci, Jambi, Indonesia. \\ *Corresponding author.Email : pramawidayat@unilak.ac.id
}

\begin{abstract}
The amount of non-organic waste produced daily by households such as plastic bags, food wraps, straws, cigarette butts and styrofoam. All of these items will not be destroyed in the soil in a short period of time because it can take decades and even hundreds of years to decompose by microbes in the soil, even styrofoam can not be destroyed. For organic waste produced by households such as food waste, fruit peels and vegetable pieces During the processing of waste, both organic and non-organic is handed over in landfill (Landfill) and one day landfill will be full so that new land should be searched. If this cycle continues, there will be a mountain of garbage and there is a gas explosion from the garbage pile. Therefore, there needs to be integrated processing carried out through waste banks, organic waste processed into compost and biopori wells. Then non-organic waste is managed and processed into ecobrik, here there is an educational value given to the community to be more concerned with environmental pollution that comes from everyday garbage. The first model run by the waste bank with the education of each household to sort the garbage from the household, where the garbage is divided in two namely: first dalah waste food waste that has been cooked such as fish bones, chicken bones and rice, this will all be included in biopori wells that are useful for the decay process and also keep the water catchment, this biopori well has a depth of 1 meter with a diamater of $6 \mathrm{~cm}$. The second is un cooked garbage such as fruit peels and pieces of vegetables, this will later be made into compost fertilizer. The second model run by waste banks is to provide education to separate non-organic waste such as plastic bags, food wraps, straws, cigarette butts and styrofoam, this will be processed into ecobrik which is paving blocks with burning process. These two models and education are expected to be a model of waste management as an environmentally friendly solution, whereby the waste bank that manages it can be established at the level of RT or RW with an average number of 200 family heads. The resulting compost and ecobrik are sold by garbage bank managers and become a source of income for the waste bank.
\end{abstract}

Keywords: Waste, Education, Organic Trash, Non Organic Waste, Compost, Bio Pori Well, Ecbolic

\section{INTRODUCTION}

The safety of the earth, how piles of plastic waste can hinder the flow of rivers that ultimately result in flooding can even damage marine ecosystems. Where Indonesia is the number 2 plastic waste producing country in the world, here are 5 countries that produce the largest plastic waste in the World that dumps its garbage into the Sea (see Table $1)$.

Meanwhile, India, which has a larger population in Indonesia, ranks number 12 in the World in producing plastic waste dumped into the Sea.
Table 1. Top five waste-producing countries

\begin{tabular}{llc}
\hline No & \multicolumn{1}{c}{ Country } & Amount of garbage (Tons) \\
\hline 1 & China & 11.5 million \\
2 & Indonesia & 3.2 million \\
3 & Filipina & 2.2 million \\
4 & Vietnam & 1.8 million \\
5 & Srilanka & 1.8 million \\
\hline
\end{tabular}

Based on the Data of the Department of Environment and Forestry that Indonesia's total waste in 2019 as much as 67 Million Tons, with the amount there is $15 \%$ of it is plastic waste or as much as 10.1 Million Tons, estimated as much 
as 3.2 Million Tons is a plastic straw. In accordance with the Indonesian Plastic Industry Association (INAPLAS) and the Central Bureau of Statistics (BPS) that Indonesia's plastic waste reaches 64 Million Tons per year, as much as 3.2 Million Tons is plastic waste dumped into the Sea.

The dominant types of plastic waste in the world include also in Indonesia today, namely :

1. Cigarette butts, According to marine conservation group, the Washington DC-based Ocean Conservancy that the most garbage found at sea are cigarette butts, their garbage collection began in 1986 and has collected 60 Million cigarette butts just around the Washington DC coast. According to the World Health Organization (WHO) that this is the habit of millions of people. Two-thirds of cigarette butts were found to be gutted and pavement. There are 6 Trillion cigarettes produced every year and more than 90 percent of the filters contain plastic. Elizabeth said working on the University of California San Francisco's tobacco control policy that the "cigarette filter" took a decade to decipher because it contained cellulose acetate. The number of cigarette butts is increasing in every area because every day the number of smokers also increases but is not accompanied by awareness of littering.

2. Food Packaging, during 2015, Our World in data produces the most types of garbage in the world, then food and beverage packaging waste reaches 146 million tons per year. It seems that this also happens on average in Indonesia including also in Riau Province

3. Plastic bag, a report from Synthesis issued by the world bank in 2018 that in Jakarta found that creek waste is very dominating, with the amount of 21.6 percent of the total garbage that exists in DKI Jakarta, and this is polluting the river in Jakarta. It is also happening in various regions in Indonesia including also in Riau province

4. Plastic Straws, Data world bank 2018 that the number of plastic straws is included in the five most found types of garbage in Indonesia. The Divers Clean Action (DCA) organization says that plastic straw waste in Indonesia reaches more than 93.2 million per day. This plastic straw takes 500 years to be deciphered naturally

5. Styrofoam, Lately people are increasingly using Styrofoam for food parcels, such as fried rice, fried noodles, chicken porridge and others. But awareness of dumping garbage in its place is very low, many found Styrofoam littering the streets. Whereas it took more than 80 years to parse it naturally

Not to mention including medical produced households such as cotton scars treating wounds, medicines and medicine packs [1],[2]. To manage this medical waste needs special handling, it should be from the household already sorting this garbage so as not to be mixed with other garbage because it can be dangerous for others including janitors who pick up garbage home.

In addition to the above non-organic waste, there is also organic waste produced by everyone in their respective residential environment. This form of organic waste such as vegetable pieces, food waste, pieces of fruit, bread and other staple foods, during this time the garbage is mostly just discarded in the environment because indeed this organic waste will be destroyed by itself, but before the garbage is destroyed, it will give rise to an unsightly aroma even causing disease [3],[4].

The low public's concern in maintaining environmental hygiene can be seen from their behavior in disposing of garbage and the way they treat garbage, they consider this garbage already exists that regulates it so that they just put it in the garbage can in front of the house and then handed over to the garbage pick-up officer. What about those who do not have a garbage can in front of his house, they hang in front of the fence of his house, garbage from the kitchen is all mixed with plastic garbage [5],[6]. It needs a strategy in tackling waste on reff [7]-[10] so as not to interfere with ecosystem sustainability [11]-[13].

Good waste management will help solve the problem of waste governance, so it is necessary to create a simple management model that can be applied in every household and educate the community to increase awareness of the dangers of waste if not managed intelligently [14]-[16].

\section{METHODOLOGY}

This research uses descriptive method with qualitative approach, data collection method using interview, observation and documentation.

Metodology missing

\section{RESULTS AND DISCUSSION}

\subsection{Current models}

At this time, the community relies more on janitors and garbage pick-ups who come to each house on the condition that they pay on a monthly basis to the officer. Garbage transported by officers will be taken to landfill, where garbage from all the city communities will be collected. In the next 5-10 years the place will be full and will be looking for a new location then this is not the right solution.

Landfill is only a short-term solution and cannot be used as a long-term solution because landfill capacity is increasingly reduced including the availability of land is also getting thinner and narrower. Not to mention the existence of landfill should not be close to public housing because it will have an impact on the quality of public health. Table 2 is an overview of the garbage in Riau Province from the Ministry of Environment and Forestry data for 2017-2018: 
Table 2. Total garbage in 2019 in Riau Province Regency/City

\begin{tabular}{cll}
\hline No & Regency/City & Amount of garbage / day \\
\hline 1 & Pekanbaru & 745.20 Ton \\
2 & Dumai & 176.00 Ton \\
3 & Kampar & 29.05 Ton \\
4 & Bengkalis & 27.00 Ton \\
5 & Indragiri Hilir & 20.00 Ton \\
6 & Kuantan Singingi & 18.14 Ton \\
7 & Siak & 12.53 Ton \\
\hline
\end{tabular}

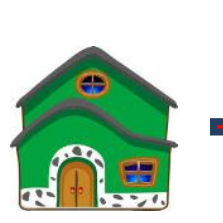

House

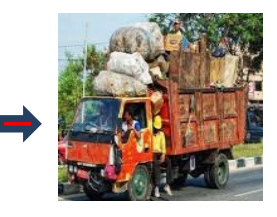

Garbage officer

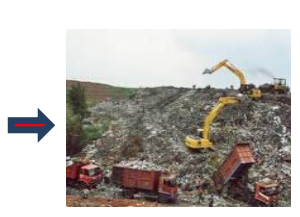

Landfill
Figure 1. Current waste disposal process

\subsection{First model: organic waste processing}

Therefore, it is necessary to establish an RW-level garbage bank that houses about 200 homes or family heads, the presence of garbage banks as a solution to the problem of garbage that is increasingly accumulating and the limitations of landfills as garbage shelters. With the waste bank program is expected to reduce the burden of landfill so that plastic waste is handed over to the Waste Bank. Invite the public to make compost fertilizer from kitchen waste such as vegetable pieces, pieces and fruit peels, leaves and the like. The manufacture of compost fertilizer can be done by every household by: cutting the garbage into small parts and after that mixed with a special liquid called EM-4 and added cow manure or black soil or if there is no then it can be replaced with existing compost fertilizer sold in agricultural stores. The manufacturing comparison is 1 kilogram of kitchen waste mixed with 1 EM-4 bottle cap and 0.5 kilograms of finished compost.

Compost fertilizer derived from organic plants is very well used as a natural fertilizer material given for home plants such as flowers and the like, and can also be used for plantations and agriculture [17],[18]. The use of natural fertilizers is a step into environmental sustainability [19][22].

In addition, kitchen waste such as food waste and fish bones and chicken bones should not be mixed with the above garbage, because garbage that has been mixed with the former frying pan will give rise to a good aroma and also the compost results are also not good. For that the rest of the kitchen waste that has been cooked then put in a bio
Pori well made as deep as 1 meter with a diameter of 5 centimeters, the garbage is put constantly full profit garbage, do not forget every finished insert then cover with perforated wire so as not to enter rats into it. If it is full then leave it for 1 month and the garbage in it will be a black soil that can be used as a medium of soil, as well as during the decay process will help moisturize the soil. Don't forget to make another new hole while waiting for the first hole process.

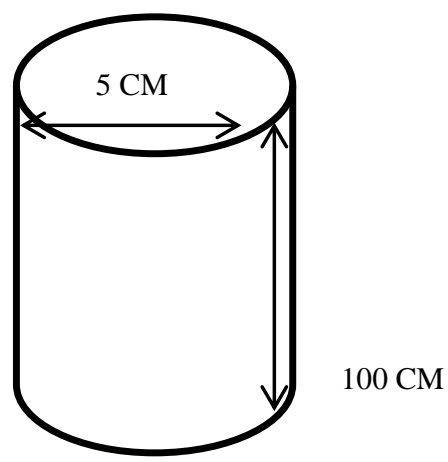

Figure 2 Biopori well shape

\subsection{Second model: non organic waste processing}

With 3 R program (Reuse, Reduce, Recycle) can reduce plastic use. "Reuse" means reusing garbage that can still be used several times such as

1. Use a napkin from a cloth instead of using tissue.

2. Using a container of used beverage cans as a place to hold cooking oil.

3. Sell and give the garbage that has been sorted to the needy such as garbage bank.

With "Reduce" means reducing something that can become garbage like the following :

1. Use refillable products such as mineral water bottles.

2. Avoid using and buying products that produce large amounts of garbage.

3. Reduce use of disposable materials.

4. Use both sides of the paper for writing or photocopy.

With "Recycle" means to reprocess garbage into useful goods such as:

1. Processing organic waste (leaves, vegetable pieces, chilies, grass) to make compost.

2. Process paper waste into paper or cardboard.

3. Do non-organic waste processing into goods of economic value. 

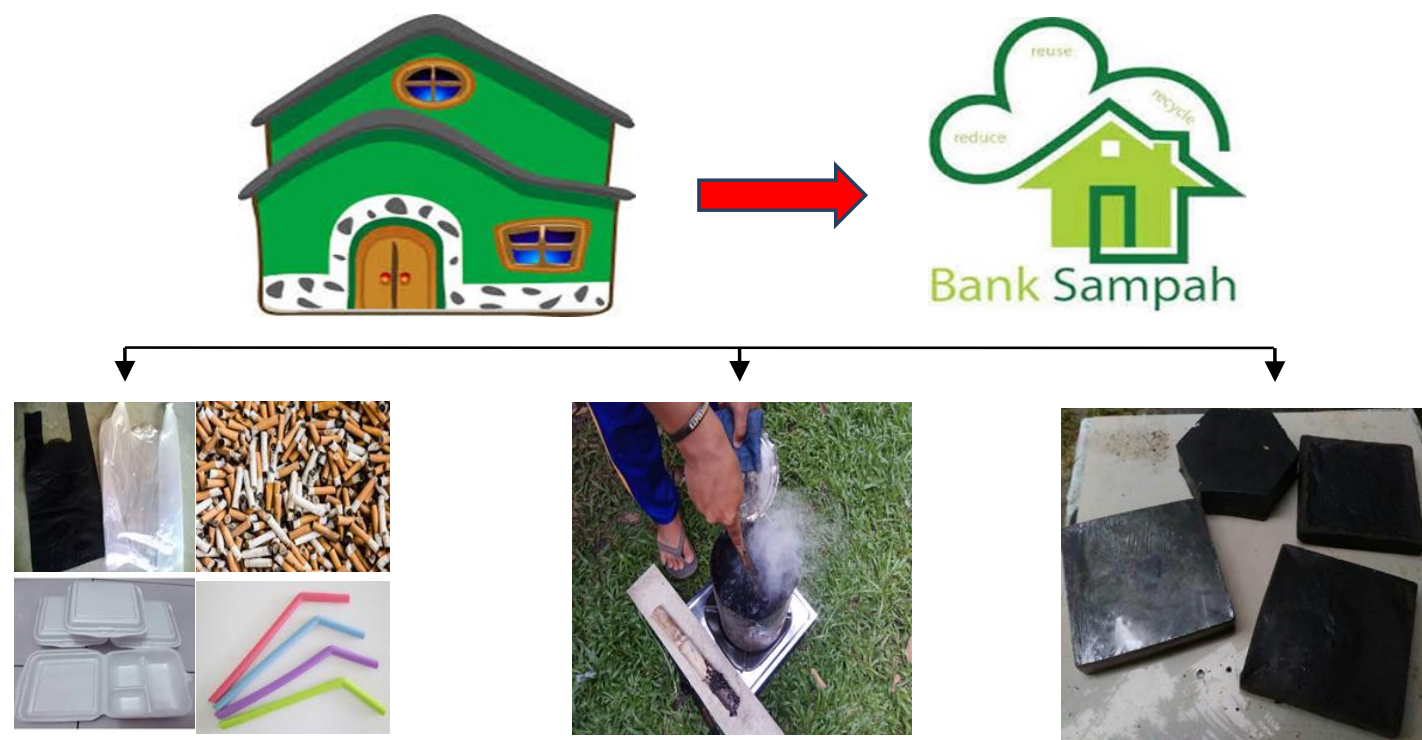

Figure 3. Ecbolic Manufactoring process

In addition, for the community is also given education that non-organic waste can be saved, as well as the types that can be saved such as paper, plastic bottles, glass bottles, cans, scrap metal and aluminum. As for the mechanism as follows: garbage is sorted from the house, after it is deposited on the garbage bank officer, then in the garbage bank will be [23],[24].

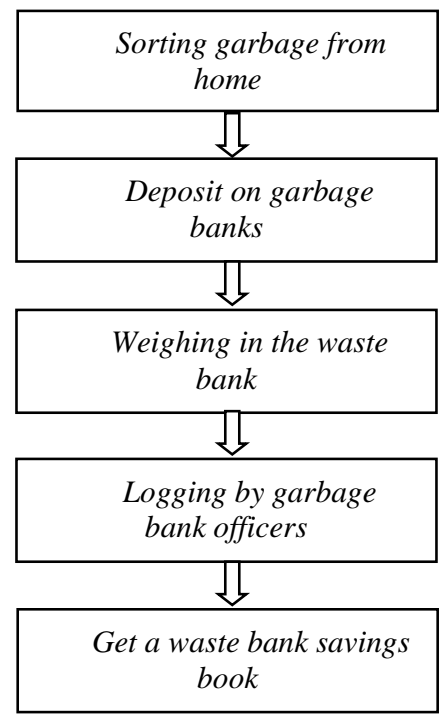

Figure 4. Junk bank mechanism

Saving money on garbage banks has at least reduced the burden of landfills that have been accommodating garbage from various places that have polluted the environment [25]-[29]
The first two models of waste management are the first model of organic waste made into compost fertilizer and made bio Pori wells, the second model of non-organic waste is made into ecbolic in the form of paving blocks. It is expected to be a solution in reducing the load of garbage that has been dumped into landfill

\section{CONCLUSION}

There are still many shortcomings in this study, where the results of the compost production need to be done laboratory tests about the nutrient content in order to be more useful for the community. As for ecbolic made in the form of paving blocks need to be done pressure test, which is to know how much ability to withstand the load because it will be installed for residential roads or office yard.

\section{REFERENCES}

[1] P. A. Abor. Medical waste management practices in a Southern African Hospital. Journal of Applied Sciences and Environmental Management, 11 (3) (2007) 25-30. DOI: 10.4314/jasem.v11i3.55136

[2] Z. Minghua, F. Xiumin, A. Rovetta, H. Qichang, F. Vicentini, L. Bingkai, L Yi. Municipal solid waste management in Pudong new area, China. Waste management, 29 (3) (2009) 1227-1233. DOI: https://do i.org/10.1016/j.wasman.2008.07.016 
[3] C. Dias-Ferreira, T. Santos, V. Oliveira. Hospital food waste and environmental and economic indicators-a Portuguese case study. Waste management , 46 (2015)146-154. DOI: https://doi.org/10.1016/j.was man.2015.09.025

[4] C. Van Dooren, O. Janmaat, J. Snoek, M. Schrijnen. Measuring food waste in Dutch households: A synthesis of three studies. Waste management, 94 (2019) 153-164. DOI: https://doi.org/10.1016/j.wasma n.2019.05.025

[5] M. Bernardo, M. Casadesus, S. Karapetrovic, I Heras. How integrated are environmental, quality and other standardized management systems? An empirical study. Journal of cleaner production, 17 (8) (2009) 742750. DOI: https://doi.org/10.1016/j.jclepro.2008.11.003

[6] B. Vrščaj, L. Poggio, F. A. Marsan. A method for soil environmental quality evaluation for management and planning in urban areas. Landscape and Urban Planning, 88 (2-4) (2008) 81-94. DOI: https://doi.org/ 10.1016/j.landurbplan.2008.08.005

[7] C. Achillas, N. Moussiopoulos, A. Karagiannidis, G. Banias, G. Perkoulidis. The use of multi-criteria decision analysis to tackle waste management problems : a literature review. Waste management \& research, 31 (2) (2013) 115-129. DOI: https://doi.org/10.1177/0734 $242 X 12470203$

[8] S. O. Ajayi, L. O. Oyedele, M. Bilal, O. .O Akinade, H. A. Alaka, H. A. Owolabi, K. O. Kadiri. Waste effectiveness of the construction industry: Understanding the impediments and requisites for improvements. Resources, Conservation and Recycling ,102 (2015) 101-112. DOI: https://doi.org/10.1016/j.res conrec.2015.06.001

[9] J. Aschemann-Witzel, I. De Hooge, A. Normann. Consumer-related food waste: Role of food marketing and retailers and potential for action. Journal of International Food \& Agribusiness Marketing, 28 (3) (2016) 271-285. DOI: https://doi.org/10.1080/0897443 8.2015 .1110549

[10] T. L. Tudor, C. L. Noonan, L. E. T. Jenkin. Healthcare waste management: a case study from the National Health Service in Cornwall, United Kingdom. Waste management, 25 (6) (2015) 606-615. DOI: https://doi.org/10.1016/j.wasman.2004.10.004

[11] D. G. Neary, C. C. Klopatek, L. F. DeBano, P. F. folliot. Fire effects on belowground sustainability: a review and synthesis. Forest ecology and management ,122 (1-2) (1999) 51-71. DOI: https://doi.org/10.1016/ S0378-1127(99)00032-8

[12] E. Ostrom. A general framework for analyzing sustainability of social-ecological systems. Science, 325 (5939) (2009) 419-422. DOI: 10.1126/science.1172133

[13] R. B. Howarth, S. Farber. Accounting for the value of ecosystem services. Ecological Economics, 41 (3) (2002) 421-429. DOI: https://doi.org/10.1016/S0921-8 009(02)00091-5

[14] D. C. Wilson, L. Rodic, A. Scheinberg, C. A. Velis, G. Alabaster. Comparative analysis of solid waste management in 20 cities. Waste management \& research, 30 (3) (2012) 237-254. DOI: https://doi.org/1 $0.1177 / 0734242 X 12437569$

[15] A. J. Morrissey, J. Browne. Waste management models and their application to sustainable waste management. Waste management, 24 (3) (2004) 297308. DOI: https://doi.org/10.1016/j.wasman.2003.09.0 05

[16] L. A. Guerrero, G. Maas, W. Hogland. Solid waste management challenges for cities in developing countries. Waste management, 33 (1) (2013) 220-232. DOI: https://doi.org/10.1016/j.wasman.2012.09.008

[17] F. Tambone, B. Scaglia, G. D'Imporzano, A. Schievano, V. Orzi, S. Salati, F. Adani. Assessing amendment and fertilizing properties of digestates from anaerobic digestion through a comparative study with digested sludge and compost. Chemosphere, 81 (5) (2010) 577-583. DOI:https://doi.org/10.1016/j.chemos phere.2010.08.034

[18] R. Gutser, T. Ebertseder, A. Weber, M. Schraml, U. Schmidhalter. Shortterm and residual availability of nitrogen after longterm application of organic fertilizers on arable land. Journal of Plant Nutrition and Soil Science, 168 (4) (2005) 439-446. DOI: https://doi.org/ 10.1002/jpln.200520510

[19] S. De Meester, J. Demeyer, F. Velghe, A. Peene, H. Van Langenhove, J. Dewulf. The environmental sustainability of anaerobic digestion as a biomass valorization technology. Bioresource technology, 121 (2012) 396-403. DOI: https://doi.org/10.1016/j.biortec h.2012.06.109

[20] P. W. Gerbens-Leenes, H. C. Moll, A. S. Uiterkamp. Design and development of a measuring method for environmental sustainability in food production systems. Ecological Economics, 46 (2) 
(2003) 231-248. DOI:https://doi.org/10.1016/S09218009(03)00140-X

[21] J. Chen, S. Lü, Z. Zhang, X. Zhao, X. Li, P. Ning, M. Liu. Environmentally friendly fertilizers: A review of materials used and their effects on the environment. Science of the Total Environment, 613 (2018) 829-839. DOI: https://doi.org/10.1016/j.scitote nv.2017.09.186

[22] F. Brentrup, J. Küsters, J. Lammel, P. Barraclough, H. Kuhlmann. Environmental impact assessment of agricultural production systems using the life cycle assessment (LCA) methodology II. The application to $\mathrm{N}$ fertilizer use in winter wheat production systems .European Journal of Agronomy, 20 (3) (2004) 265279. DOI: https://doi.org/10.1016/S1161-0301(03)000 39-X

[23] J. Baeyens, A. Brems, R. Dewil. Recovery and recycling of post-consumer waste materials. Part 1 . Generalities and target wastes (paper, cardboard and aluminium cans). International Journal of Sustainable Engineering, 3 (3) (2010) 148-158. DOI: https://doi.org $/ 10.1080 / 19397038.2010 .498529$

[24] M. E. Kaseva, S. E. Mbuligwe, G. Kassenga. Recycling inorganic domestic solid wastes: results from a pilot study in Dar es Salaam City, Tanzania . Resources, Conservation and Recycling, 35 (4) (2002) 243-257. DOI: https://doi.org/10.1016/S0921-3449(02) 00004-6

[25] C. Cimpan, M. Rothmann, L. Hamelin, H. Wenzel. Towards increased recycling of household waste: Documenting cascading effects and material efficiency of commingled recyclables and biowaste collection. Journal of Environmental Management, 157 (2015) 69-83. DOI: https://doi.org/10.1016/j.jenvman .2015 .04 .008

[26] S. H. Fauziah, P. Agamuthu. Trends in sustainable landfilling in Malaysia, a developing country. Waste Management \& Research, 30 (7) (2012) 656-663. DOI: https://doi.org/10.1177/0734242X12437564

[27] J. Beall. Thoughts on poverty from a South Asian rubbish dump: gender, inequality and household waste. IDS Bulletin, 28 (3) (1997) 73-90. DOI: https:// doi.org/10.1111/j.1759-5436.1997.mp28003006.x

[28] M. S. Korai, R. B. Mahar, M. A. Uqaili. The feasibility of municipal solid waste for energy generation and its existing management practices in Pakistan. Renewable and Sustainable Energy Reviews, 72 (2017) 338-353. DOI: https://doi.org/10.1 016/j.rser.2017.01.051
[29] H. Bulkeley, N. Gregson. Crossing the threshold: municipal waste policy and household waste generation. Environment and planning A, 41 (4) (2009) 929-945. DOI: https://doi.org/10.1068/a40261 